\title{
Trends in the development of Civil Law
}

\author{
$1 \mathrm{PhD}$, Associate Professor, Altai State University, Barnaul, Russian Federation. \\ E-mail: kovalenko1288@mail.ru (iD https://orcid.org/0000-0001-6017-8933 \\ 2 PhD, Associate Professor, Ural State Law University, Yekaterinburg, Russian Federation. \\ E-mail: kke@email.asu.ru (iD https://orcid.org/0000-0001-6322-9388 \\ 3 Altai State University, Barnaul, Russian Federation. \\ E-mail: kke@email.asu.ru (D) https://orcid.org/0000-0003-4961-9480
}

\author{
Kseniya E. Kovalenko ${ }^{1}$ \\ Anna V. Gubareva ${ }^{2}$ \\ Nataliya E. Kovalenko ${ }^{3}$
}

\begin{abstract}
The issue of exempting self-employed Russians from taxes and mandatory contributions in Russia remained open for a long time. The solution of this issue remained relevant for long due to the fact that in Russia millions of people work independently in different spheres (from minor repairs and construction to car-care auto centers).
\end{abstract}

Keywords: Self-employed, Economy, Individual entrepreneur, Wokers, Law.

\section{Introduction}

Civil law is a branch of law that regulates civil law relations. With the stages of the development of civil law, many researchers relate the main stages of world history, that is: Ancient Rome, the Middle Ages, the Renaissance, bourgeois revolutions, etc.

Of course, the branch of civil law did not appear on its own: its formation took a rather large amount of time. Civil law has developed over several centuries and is currently continuing to evolve and change. So, the stages of development of civil law in Russia originate in ancient Rome. At that time, it was formed on the basis of customary law, as well as judicial practice. In the future, when precedents and judicial practice became insufficient to regulate public relations, the legal provisions proposed by Roman lawyers and adopted by law came to the fore. In the days of the Roman Empire, civil law looked like a complex of legal institutions, which was mainly regulated only by commodity relations, that is, relations arising, for example, during the sale. It is believed that it was Roman law, as the most de- veloped and developed, that formed the basis of modern civil law.

Moving further along the chronological chain, one cannot fail to note such a stage in the development of civil law as the Middle Ages. To determine the features of civil law of that time, it is necessary to clarify that the basis of society then was subsistence farming. In this regard, civil law was a combination of decentralized local norms.

Interest in the legal norms of Ancient Rome reawakened during the Renaissance. At that time, numerous commentaries on Roman law were created, which ensured its partial implementation in the legal systems of that time.

XVII-XVIII centuries became the time of the beginning of a serious codification of civil law. It is worth noting that this happened after the bourgeois revolutions, when the population expressed their dissatisfaction with the then existing social system. This fact explains why problems that have arisen in society have been resolved by incorporating Roman law into the civil law system. The countries implementing this project are Germany with its 
German Civil Code, France with the Civil Code of Napoleon, as well as Austria.

At the same time, in some countries, commercial law gradually began to separate from civil law. It is also interesting that Trade Codes were often created much earlier than the Civil Codes.

As for our country, the first reduction of civil legal norms came together in the first half of the 19th century. This document was prepared by M. M. Speransky and was called the "Code of Laws of the Russian Empire". In the late XIX - early XX centuries, attempts were made to change the code of laws in accordance with the peculiarities of the development of society of that period, but the First World War violated these plans.

The first Civil Code for Russia was adopted only in 1922 in the USSR. Due to the fact that the USSR was characterized by a command type of economy, the list of areas of application of civil law in the Union was significantly reduced.

After the collapse of the USSR, Russia adopted the first part of the Civil Code of the Russian Federation in 1994. At present, the Civil Code of the Russian Federation consists of four parts, is constantly being reviewed and supplemented.

In September 2016, the question of the need to solve the problem of self-employed Russians was raised by President of Russia Vladimir V. Putin. "We have repeatedly discussed both on party forums within the framework of "United Russia", on AllRussian People's Front media forum about the need for a certain period, for two years, completely liberate self-employed from paying taxes and mandatory contributions", - Putin said. The problem of the self-employed population was clearly identified by the Russian president. It consists in the fact that people are sometimes forced to "remain in the shadows" in order to avoid a clash with bureaucracy, bribes, and checks. There was a real need to offer, finally, to the self-employed population a clear and convenient tool of interaction with the state in order to legalize their activities, to earn honestly due to their work and abilities.

In February 2017, following Putin's proposal, Russian Prime Minister Dmitry A. Medvedev proposed to introduce a notification procedure for registration (according to various estimates, 15-25 million self-employed with two-year tax holidays). It would seem that a two-year vacation should definitely be welcomed by self-employed citizens. They need to declare themselves, which guarantees them no tax losses. However, the effect of these norms is limited to the period 20172018. In this regard, it seems insufficient to provide self-employed two-year tax holidays for the purpose of their legalization. Further clarification is needed on what awaits the selfemployed after the end of the two-year tax holidays. Specification, in particular, requires the fact whether they will have to pay personal income tax, and insurance premiums according to the tariff that is valid today for individual entrepreneurs. Here is what Lashkina E., an assistant to the Minister of Economic Development, replied: "It is important to avoid abuse, and minimize risks. Registering such Russians as individual entrepreneurs is no longer planned, now their status will be defined as "self-employed citizens".

\section{Development}

The value of the principle of permissible orientation of civil law regulation in a market economy is extremely high. A market economy can develop successfully only if the subjects of civil law have the necessary freedom, show enterprise, initiative and other activity in the field of civil turnover. The latter would not have been possible without the principle of the permissible orientation of civil law regulation of public relations embodied in civil 
law.

The rules of law contained in civil law are formulated on the basis of the general rule: "All that is not prohibited by law is permitted." In accordance with it, public interests, enshrined in the regulatory restrictions on freedom of action in the private interest, have an unconditional priority. However, within the framework of these restrictions, subjects of civil law can perform any actions not prohibited by law. In particular, citizens and legal entities vested with general legal capacity may engage in any type of entrepreneurial and other activity not prohibited by law (Articles 18, 49 of the Civil Code of the Russian Federation).

Most of the norms of civil law are of a dispositive nature, therefore, subjects of civil law can exercise their legal capacity at their discretion, acquire subjective rights or not acquire them, choose a specific method of their acquisition, regulate at their discretion the content of the legal relationship of which they are participants, to dispose of owned subjective rights, to resort or not to resort to measures to protect the violated right, etc.

Subjects of civil law can acquire rights and assume obligations not only directly stipulated by law and other legal acts, but also not directly reflected in civil law, if they do not contradict the general principles and meaning of civil law (clause 2 of article 8 of the Civil Code of the Russian Federation )

The most effective development of civil turnover occurs when its participants enter into relations with each other and carry out their activities within the framework of these relations in accordance with their interests embodied in their rights.

The subjects of civil law, at their discretion, exercise their civil rights (Clause 1, Article 9 of the Civil Code of the Russian Federation), and this discretion in the exercise of their rights is based only on their property and other interests. No one can dictate to participants in civil relations how to exercise their rights.

However, the discretion of participants in civil relations is not unlimited and exists within a certain legal framework. So, in accordance with paragraph 1 of Art. 10 of the Civil Code of the Russian Federation, civil rights are not allowed to restrict competition. In h. 3 Article. 55 of the Constitution of the Russian Federation and paragraph 2 of article 1 of the Civil Code of the Russian Federation, it is established that civil rights can be limited on the basis of federal law only to the extent necessary to protect the foundations of the constitutional order, morality, health, rights and legitimate interests of others, to ensure national defense and state security. These norms reflect the most optimal combination of private and public interests in civil society.

A participant in a civil legal relationship may use his right, or may not use it, refusing to exercise it. Moreover, the refusal of citizens and legal entities to exercise their rights does not entail the termination of these rights, with the exception of cases provided for by law (clause 2 of article 9 of the Civil Code of the Russian Federation). In particular, the right to judicial protection does not cease to exist in the reservation made by the parties to the agreement that all disagreements between them are resolved without going to court.

Since the exercise and protection of civil rights depends on the discretion of participants in civil turnover, state and local authorities, as well as other persons, are not entitled to force participants in civil legal relations to exercise or protect their subjective rights. Legal acts also cannot establish the obligation of participants in civil relations to exercise or protect their rights and, moreover, impose sanctions on those who do not sue for the protection of violated civil rights.

The principle of equality of the legal regime for all subjects of civil law means that not a single subject of civil law has any advantages over other entities. One of the manifestations 
of this principle is that many rules of law apply to relations with the participation of citizens, legal entities, as well as Russia, constituent entities of the Federation, and municipalities. So, for all subjects of civil law, a threeyear limitation period is established. In the sub-sector "ownership and other property rights", this principle is embodied in the rule that the rights of all owners are protected in the same way (Clause 4, Article 212 of the Civil Code of the Russian Federation).

For a long time, there was no legal definition of the term "self-employed" at all. In March 2017, the Ministry of Justice sent a report to the government, called upon to close discussion on this issue between the departments. The Ministry of Justice defined the self-employed as citizens who independently and systematically earn on the services provision and work performance for individuals. By definition, such a citizen cannot be registered as an individual entrepreneur and should not have hired workers. The definition itself narrowed the circle of selfemployed persons. However, it should be noted that today the topic of self-employed citizens is only partially reflected in legislation, since in November 2016 the State Duma adopted amendments to the tax code on twoyear tax holidays so far only for three categories of self-employed: domestic workers, nannies (nurses), and tutors. The Ministry of Justice has proposed not to adopt a special law on self-employed persons because of its inexpediency, and since this law will not have an independent subject of regulation, and proposed to fix the necessary criteria in the "On Employment" Law. So, according to the definition of the Ministry of Justice, a selfemployed person can be considered "an individual who independently carries out at his own risk the activity of the services provision and work performance for individuals, aimed at systematic profit-making based on his personal participation". The self-employed per- son cannot be registered as an individual entrepreneur and have hired workers. But such a definition does not give an opportunity to refer to self-employed citizens who lease out real estate due to lack of "labor participation", as well as earning their own or foreign products and dealing with organizations. Thus, in addition to domestic workers, nannies (nurses) and tutors who have received tax holidays, according to this definition, the ranks of selfemployed people can be replenished by a few: those who earn repairs, transfers, household services, etc. As for the specifics of registration of self-employed persons, the Ministry of Justice proposes to establish them in the "On state registration of legal entities and individual entrepreneurs" Law. The basis for starting a self-employed citizen can be a notification, for example, to the tax inspection through a single portal of public services, the Multifunctional center or the employment service. There is also no certainty with taxes of the self-employed: the Ministry of Justice only indicates that for the purposes of taxation it is required to determine the types of activity of self-employed. In addition, it is necessary to decide whether to confirm the qualification in cases when for a certain type of activity, it is necessary to meet certain requirements.

Fixing the concept of self-employed in the "On employment" Law does not require its definition in the Civil Code. The deputy bill on the amendment to the Civil Code, introduced by Krasheninnikov P. and Makarov A. in the State Duma, provides a reference rule that with regard to certain types of activity, laws may provide for the conditions for citizens to perform activities without registration as an individual entrepreneur. The Ministry of Justice also proposes to amend the Tax Code, the Labor Code, the Law on State Registration of Legal Entities and the Code of Administrative Offenses in addition to the "On Employment" Law. In order to achieve the goal of legalization of the self-employed, the Min- 
istry of Justice proposes, as incentives for this group of citizens, to offer informational, advisory, property and educational support.

It seems necessary to refine the definition of self-employed persons proposed by the Ministry of Justice, since the existing considerably narrows the number of self-employed for their possible legalization. And this kind of activity, like trade, does not fall under the legalization at all.

The law adopted by the State Duma on the legal status of self-employed citizens requires special consideration. In the third reading, the State Duma adopted amendments to the Civil Code of the Russian Federation on the determination of the legal status of selfemployed citizens. The introduced changes will allow the population to carry out certain types of entrepreneurial activity without state registration as an individual entrepreneur. According to the author of the bill Krasheninnikov P., the amendments will help legalize the activities of millions of self-employed citizens of the Russian Federation without the need to collect and submit a variety of different documents.

In the draft law published by the Justice Ministry, in addition to identifying selfemployed citizens, it is noted that these persons must be over 16 years old. Another criterion is the provision of notification of the implementation of this activity to the tax service. After the adoption in November 2016 of a law on two-year tax holidays for housekeepers, nurses and tutors for three months of the program, 40 people registered. This figure, of course, is not indicative of the particular success of the campaign to legalize the incomes of Russians working for themselves. So, from January 1, 2017, Art. 217 of the Tax Code is supplemented with par. 70, which is devoted to self-employed persons of the Russian Federation. This norm dictates that personal income tax is not levied on income received by individuals (who are not individual entrepre- neurs) from individuals for providing them with the following services for personal, domestic and other needs. These are the following:

- supervision and care of children, sick persons, persons who have reached the age of 80 years, as well as for other persons who need constant care by persons from the side on the conclusion of medical organizations;

- tutoring;

- cleaning of living quarters;

- housekeeping.

In this case, an individual may use this privilege only if the following conditions are met: (a) the individual performs the services solely on his own, without involving other persons to help himself; (b) an individual is obliged to notify the tax authority of the implementation (termination) of activities to provide services to an individual for personal, domestic and other similar needs. Therefore, the tax registration of such a self-employed person is made by the tax authority at the place of his residence (or place of stay in the event that there is no residence in the territory of the Russian Federation). For convenience, self-employed citizens are allowed to file a notification to any tax authority in accordance with the contents of Clause 7.3, Art. 83 of the Tax Code. This notification can be submitted by a self-employed citizen personally or through a representative, mailed by registered mail or transmitted on the Internet in electronic form (in this case, the notice must be completed by the enhanced qualification of the digital signature).

In any case, according to par. 2 of Art. 84 of the Tax Code, a notice of registration or withdrawal from the tax inspection is not issued. For the self-employed, put on the tax account, an additional bonus is given, namely: their incomes are not assessed with contributions to extra-budgetary funds (subpar. 3 of clause 3 of Art. 422 of the Tax Code of the Russian Federation). In this case, according to 
par. 7 of Art. 431 of the Tax Code, their employers should not submit calculations on insurance premiums. At the same time, anyone can find out whether the activities of a self-employed person are legally conducted, since in accordance with Clause 7.3, Art. 83 of the Tax Code of the Russian Federation, information on the registration of individuals on the tax account does not apply to tax secrecy.

\section{Result}

It should be noted that recent years have been marked by increased attention to the problem of legalization of shadow incomes of self-employed citizens of the Russian Federation, especially by legal experts. One of the critically inclined to legislative changes is Lysenko E.D. In work "Actual problems of the legal regulation of self-employment" the author on the basis of statistical research has revealed the characteristic signs of selfemployment. Based on them, Lysenko analyzes the shortcomings of the existing tax legislation, discusses the preferred directions for further reforms.

In the first part of "The concept and economic essence of self-employment" article the bachelor of jurisprudence shapes the idea of the place of self-employed in the Russian economy, represents the "average portrait" of a self-employed citizen. The difficulty is even in determining the number of part of the population that can be attributed to the selfemployed. There is not even a single opinion on the subject of being classified as selfemployed. In the Russian legislation, it is difficult to find the definition of the term "selfemployed". According to one of the definitions, "A self-employed person who is selfemployed in providing services under civil law contracts, including in the form of an individual entrepreneur" . In this definition, the absence of labor relations is named as a qualify- ing feature. The self-employed does not act either as an employer or an employee who provides services on his own. In the author's opinion, the definition in question fully corresponds to the economic essence of the phenomenon under investigation. Therefore, with the economic point of view to the selfemployed can be attributed the persons who perform on a reimbursable basis some function, and not in labor relations. In fact, selfemployed citizens are a border category that combines the characteristics of both the employee and the entrepreneur. At the same time, self-employed people cannot be classified as hired workers or entrepreneurs because they do not act as one of the parties to the employment relationship. Here the term "labor relations" covers the relationship of the employer and the employee, regardless of the form of their legal securing. For example, a student who was attracted to distribute advertising leaflets on the basis of a contract for paid services would not be classified as selfemployed. It is also important to note that in the context of economic research, the issue of self-employment is usually considered in connection with the issue of informal employment.

\section{Conclusion}

With the transition of the country to a society with a market economy, the direction of scientific research has changed dramatically. The agenda included the solution of pressing issues related to private property law, which became the main form of ownership in the country, participation in the civil turnover of business partnerships and societies, freedom of contract, personal non-property rights of citizens, intellectual property. The studies on the participation of civil law in the comprehensive regulation of public relations, on increasing the role of law enforcement practice in connection with the adoption of the Civil 
Code of the Russian Federation and the creation of a modern concept of civil law as one of the main branches of Russian law, are becoming extremely relevant.

In the scope of its application, civil law as a branch of legal science goes beyond the scope of civil law as a branch of law and branch of law. In addition to these areas, it, in particular, includes the identification of patterns that determine the relationship of civil law with related public structures, relations, as well as branches of science and knowledge in the field of economics, ecology, sociology, philosophy, psychology, political science, etc.

It should be noted that recent years have been marked by increased attention to the problem of legalization of shadow incomes of self-employed citizens of the Russian Federation, especially by legal experts. One of the critically inclined to legislative changes is Lysenko E.D. In work "Actual problems of the legal regulation of self-employment" the author on the basis of statistical research has revealed the characteristic signs of selfemployment. Based on them, Lysenko analyzes the shortcomings of the existing tax legislation, discusses the preferred directions for further reforms.

In the first part of "The concept and economic essence of self-employment" article the bachelor of jurisprudence shapes the idea of the place of self-employed in the Russian economy, represents the "average portrait" of a self-employed citizen. The difficulty is even in determining the number of part of the population that can be attributed to the selfemployed. There is not even a single opinion on the subject of being classified as selfemployed. In the Russian legislation, it is difficult to find the definition of the term "selfemployed". According to one of the definitions, "A self-employed person who is selfemployed in providing services under civil law contracts, including in the form of an individual entrepreneur". In this definition, the ab- sence of labor relations is named as a qualifying feature. The self-employed does not act either as an employer or an employee who provides services on his own. In the author's opinion, the definition in question fully corresponds to the economic essence of the phenomenon under investigation. Therefore, with the economic point of view to the selfemployed can be attributed the persons who perform on a reimbursable basis some function, and not in labor relations. In fact, selfemployed citizens are a border category that combines the characteristics of both the employee and the entrepreneur. At the same time, self-employed people cannot be classified as hired workers or entrepreneurs because they do not act as one of the parties to the employment relationship. Here the term "labor relations" covers the relationship of the employer and the employee, regardless of the form of their legal securing. For example, a student who was attracted to distribute advertising leaflets on the basis of a contract for paid services would not be classified as selfemployed. It is also important to note that in the context of economic research, the issue of self-employment is usually considered in connection with the issue of informal employment.

\section{References}

BELYAEV, K. M., ROMANOV, A. A. Cyber security of unmanned vehicles. Technical and technological problems of service. St. Petersburg: Publishing House St. Petersburg State University of Economics, 2018, 2.

CHOPRA, S., WHITE, L. Artificial Agents. Personhood in Law and Philosophy. URL: https://philpapers.org/rec/CHOAA (accessed October 1, 2019).

DUGGAL, P. Artificial intelligence law. 2017.

KOSTOMAROVA, V. V. Foreign experience 
in implementing intelligent transport systems (ITS). Actual problems of the humanities and natural sciences. 2016, 4-1.

KOVALENKO, K. E., ROZENTSVAIG, A. I., GUBAREVA, A.V. International terrorism and international cyberterrorism. Quidinvestigacion ciencia y tecnologia. 2018, 2 (SI).

Legal battle: a robot from Megafon vs Roman Bevzenko. URL: https://pravo.ru/lf/story/ 202675/ (accessed October 1, 2019)

LYSENKO, E. D. Actual problems of legal regulation of self-employment. Public-legal studies. 2017, 2.

On national goals and strategic objectives of the development of the Russian Federation for the period until 2024: Decree of the President of the Russian Federation of May 7, 2018 No. 204.

POPKOVA, Zh. G. A new category of selfemployed persons. Law and Economics. 2017, 2.

TYUTIN, D. V. Tax law. Moscow, 2015.

VDOVIN, R. A., ROZENTSVAİG, A. I., KOVALENKO, K. E., Kovalenko, N. E. Defects of terminology in law and technique. Religacion-revista de ciencias sociales y humanidades. 2019, 4(18) SI.

Putin proposed to exempt self-employed Russians from taxes. URL: https://lenta.ru/ news/2016/09/21/selfemploy.

LYSENKO, E. D. Actual problems of legal regulation of self-employment. Public-legal studies. 2017, 2.

PORTA, R., SHLEIFER, A. The Unofficial Economy and Economic Development. Brookings Papers on Economic Activity. 2008. https://doi.org/10.3386/w14520

Official site of the Federal State Statistics Service. URL: http://www.gks.ru/wsp/wcm/ connect/rosstat_main/rosstat/ru/statistics/ wages/labour_force/\#

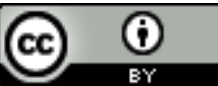

License information: This is an openaccess article distributed under the terms of the Creative Commons Attribution License, which permits unrestricted use, distribution, and reproduction in any medium, provided the original work is properly cited.

Article received on November 10, 2019.

Evaluated November 15, 2019.

Accepted on November 15, 2019.

Published on November 21, 2019.

How cite this article (ABNT):

KOVALENKO, Kseniya E.; GUBAREVA, Anna V.; KOVALENKO, Nataliya E. Trends in the development of Civil Law. Estação Científica (UNIFAP), Macapá, v. 9, n. 2, p. 79-86, apr./jun. 2019. 